\title{
Occurrence and genetic characterization of Echinococcus granulosus sensu lato from domestic animals in Central Iran
}

\author{
Bahador Hajimohammadi ${ }^{1,2}$, Abdolhossein Dalimi ${ }^{3}$, Gilda Eslami ${ }^{4^{*}}$ D, Salman Ahmadian 1,4, \\ Sajad Zandi ${ }^{1,4}$, Ahmad Baghbani ${ }^{1,2}$, Saeedeh Sadat Hosseini', Vahideh Askari ${ }^{1}$, Maryam Sheykhzadegan ${ }^{1}$, \\ Mehrnoosh Nabizadeh Ardekani ${ }^{5}$, Mohammad Javad Boozhmehrani ${ }^{1,4}$, Mohammad Javad Ranjbar', \\ Hamed Ghoshouni ${ }^{1}$ and Mahmood Vakili ${ }^{6}$
}

\begin{abstract}
Background: The species complex of Echinococcus granulosus sensu lato (s.l.) causes cystic echinococcosis distributed worldwide. There is no genotype information from hydatid cysts in the intermediate hosts in Central Iran. Therefore, in this study, we analyzed the hydatid cysts in livestock slaughtered in an abattoir in this region. Six hundred fifty-seven hydatid cysts were isolated from 97 animals, including sheep, cattle, camels, and goats slaughtered in Yazd abattoir from September 2018 to January 2020. The demographic data was collected as well as cyst location, fertility, and viability. Out of 657 samples, 164 samples were genotyped. Then, phylogenetic analysis was performed using MEGAX. Statistical analyses were done using SPSS version 16.0 by chi-square with a significant difference of less than 0.05 .

Results: Out of 164 samples, the G1-G3 complex genotype had the most frequency in samples, with 135 cases recognized. The G6/G7 was observed in 19 isolates and G5 was reported in nine samples. One sample was detected as Taenia hydatigena.

Conclusions: This study showed that G1-G3 and G6/G7 genotypes were presented in all animals, but G5 was reported only in cattle, goats, and camels. It is the first molecular identification of cystic echinococcosis in Central Iran. Hence, reporting G5 in livestock in this area should be considered due to transmission to humans.
\end{abstract}

Keywords: Echinococcus granulosus sensu lato, Livestock, Cytochrome C oxidase subunit 1, Food safety, Genotypes

\section{Background}

The species complex of Echinococcus granulosus sensu lato (s.l.) is a parasite causing cystic echinococcosis (CE) [1]. Echinococcosis is one of the most important tropical diseases worldwide distribution due to its remarkable economic damages [2]. Livestock such as

*Correspondence: eslami_g2000@yahoo.com

${ }^{4}$ Department of Parasitology and Mycology, School of Medicine, Shahid

Sadoughi University of Medical Sciences, Yazd, Iran

Full list of author information is available at the end of the article sheep, cattle, goats, and camels acts as intermediate hosts, which harbor metacestodes in the liver, lung, and other internal organs. Besides, adult tapeworms are in the intestine of wild and domestic canids that serve as definitive hosts [3].

E. granulosus s.l. is composed of distinct genotypes that are divided into E. granulosus sensu stricto (genotype G1-G3 exist in sheep and buffalos), E. equinus (G4 found in horses), E. ortleppi (G5 in cattle), and E. canadensis (G6/G7, G8, and G10) [4]. The most eminent genotype in the world is G1 (sheep) [5]. 


\section{Prevalence of infected livestock per} sexes

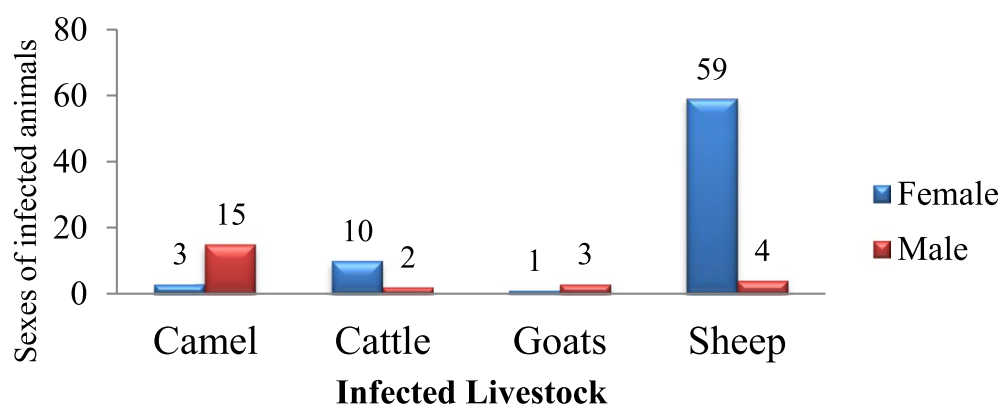

Fig. 1 The prevalence Echinoccus granulosus s.l. per sexes in slaughtered livestock

The echinococcosis has been reported in Australia, northern and eastern Africa, Central Asia, and some Mediterranean countries [6, 7]. Additionally, infection in livestock and ruminants has been described in different parts of Iran [8]. Several slaughterhouses in Iran have a total prevalence of $5-72 \%$ in sheep, $11.4-70 \%$ in camels, $3.5-38 \%$ in cattle, and $1.7-20 \%$ in goats [9-11].

Based on the available evidence, some genotypes have higher pathogenicity for humans than others, so the determination of E. granulosus s.l. genotype is essential for disease control, drug reactions, and prevention in different geographical areas [12-14]. Based on sequence analysis and further techniques conducted in Iran and other countries, the dominant genotypes include G1-G3 and G6/G7 [15]. No study has been conducted regarding the molecular identification of E. granulosus s.l. in Central Iran. To increase knowledge of the genotype spectrum involving $\mathrm{CE}$ in Central Iran, the present study was conducted to evaluate the genetic variation of Echinococcus granulosus s.l. in livestock slaughtered in this area.

\section{Results}

The hydatid cysts included in this study were obtained from livestock, including sheep, camels, goats, and cattle. The cyst locations were in both animal liver and lung with the rate of $38.1 \%$ in sheep with both lung and liver infection; $38.9 \%$ of camels had both lung and liver infection, $25 \%$ of cattle had both lung and liver infection, and $50 \%$ of goats were infected in both lung and liver. One sample was detected as Taenia hydatigena. The identified E. granulosus s.l. genotypes were G1-G3, G6/G7, and G5. One crucial piece of data shown in this study was that more than one genotype was identified in one animal species infected with hydatid cysts. One goat had two cysts in the lung with two different genotypes of G1-G3 and G6/G7. In cattle, two had cysts in their lungs with two different genotypes of G1-G3 and G5 and one had co-infection of two genotypes of G1-G3 and G6/G7 in the lung. In camels, four animals had co-infection of G1-G3 and G6/G6 genotypes, two had co-infection of G1-G3 and G5 genotypes, and one had three genotypes of G1-G3, G6/G7, and G5. In sheep, co-infection has not been recorded.

\section{Prevalence of infection per sex}

Among 97 infected animals, 75.3\% (73/97) were female, including $1.4 \%(1 / 73)$ of goats, $80.8 \%(59 / 73)$ of sheep, $4.1 \%(3 / 73)$ of camels, and $13.7 \%(10 / 73)$ of cattle. The male with echinococcosis was $24.7 \%$ (24/97) comprising $16.7 \%$ (4/24) sheep, $12.5 \%$ (3/24) goats, 8.3\% (2/24) cattle, and $62.5 \%(15 / 24)$ camels (Fig. 1). Regarding infection in each animal species per sex, it was $93.7 \%$ (59/63) female and $6.3 \%(4 / 63)$ male in sheep, 25\% (1/4) female and $75 \%(3 / 4)$ male in goats, $83.3 \%(10 / 12)$ female and $16.7 \%$ $(2 / 12)$ male in cattle, and $16.7 \%(3 / 18)$ female and $83.3 \%$ $(15 / 18)$ male in camels.

\section{Prevalence of infection per age}

Out of 97 infected animals, 70.1\% (68/97) were 1 to 5 years old, including $76.5 \%$ (52/68) of sheep, 5.9\% (4/68) of goats, $13.2 \%$ (9/68) of cattle, and 4.4\% (3/68) of camels; and $29.9 \%$ (29/97) were more than 5 years old comprising $37.9 \%(11 / 29)$ of sheep, $10.3 \%(3 / 29)$ of cattle, and $51.8 \%$ $(15 / 29)$ of camels. The most infected sheep, goats, and cattle were 1 to 5 years old, and the most infected camels were more than 5 years old (Fig. 2). Regarding each animal species, $82.5 \%(52 / 63)$ of sheep were 1 to 5 years old, and $17.5 \%(11 / 63)$ were more than 5 years old; all goats were 1 to 5 years old; $75 \%$ (9/12) of cattle were 1 to 5 years old, and $25 \%(3 / 12)$ were more than 5 years old; and finally, $16.7 \%(3 / 18)$ of camels were 1 to 5 years old, 


\section{Prevalence of hydatid cysts per ages of infected livestock}

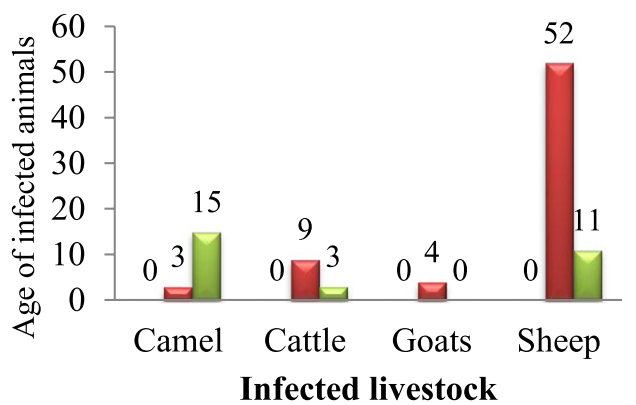

$\square$ less than 1 years-old

$\square 1$ to 5 years-old

$\square$ more than 5 years-old

Fig. 2 The prevalence Echinoccus granulosus s.l. per ages in slaughtered livestock



Fig. 3 The prevalence Echinoccus granulosus s.l. per cyst locations in slaughtered livestock

and $83.3 \%(15 / 18)$ were more than 5 years old. None of the infected animals was less than 1 year old.

\section{Prevalence of infection per cyst location}

From 657 hydatid cysts obtained from 97 animals, the distribution of cysts in the lung and liver was almost the same in sheep, goats, and cattle. However, in camels, the lung had more cysts than the liver. Out of 657 cysts, $46.1 \%$ (303/657) samples were obtained from the animals' liver, including $71.3 \%(216 / 303)$ of sheep, $19.8 \%(60 / 303)$ of cattle, $6.6 \%(20 / 303)$ of camels, and $2.3 \%(7 / 303)$ of goats. The hydatid cysts in animals' lung were $53.9 \%$ (354/657), including $61.6 \%(218 / 354)$ in sheep, $20.3 \%(72 / 354)$ in camel, $16.4 \%(58 / 354)$ in cattle, and $1.7 \%(6 / 354)$ in goats (Fig. 3). Regarding the animal species and the cysts' location, its prevalence in the goat liver was $53.8 \%$, and in the goat lung was $46.2 \%$. Besides, it was $49.8 \%$ in sheep liver and $50.2 \%$ in sheep lung. This presence was $50.8 \%$ in cattle liver and $49.2 \%$ in cattle lung; and $21.7 \%$ in camel liver and $78.3 \%$ in camel lung.

\section{Fertility and viability}

Out of 657 samples, 357 (54.3\%) were fertile, including $87.4 \%(312 / 357)$ of sheep, $0.8 \%$ (3/357) of goats, and $11.8 \%(42 / 357)$ of camels. None of the cysts in camels were fertile. Regarding each animal species, the rate of hydatid cysts fertility in sheep was $71.9 \%$ (312/434), it was $23 \%(3 / 13)$ in goats and $45.7 \%(42 / 92)$ in camels. Out of 357 fertile cysts in animals, $96.6 \%(345 / 357)$ had viability, including $88.7 \%(306 / 345)$ in sheep, $0.9 \%(3 / 345)$ in goats, and $10.4 \%(36 / 345)$ in camels. Respective in each animal, the viability rate of the fertile cysts was $98.1 \%$ $(306 / 312)$ in sheep and $85.7 \%(36 / 42)$ in camels. All fertile cysts in goats had viability (Fig. 4).

The descriptive analysis showed that $75.3 \%$ of the infected animals were female. The chi-square analysis indicated that infection rate and sex had a significant relationship $(p=0.00001)$. The infection rate at the age of 1 to 5 was $70.1 \%$, and the remaining was regarding the animals more than 5 years old. The statistical analysis showed significant differences among the age 


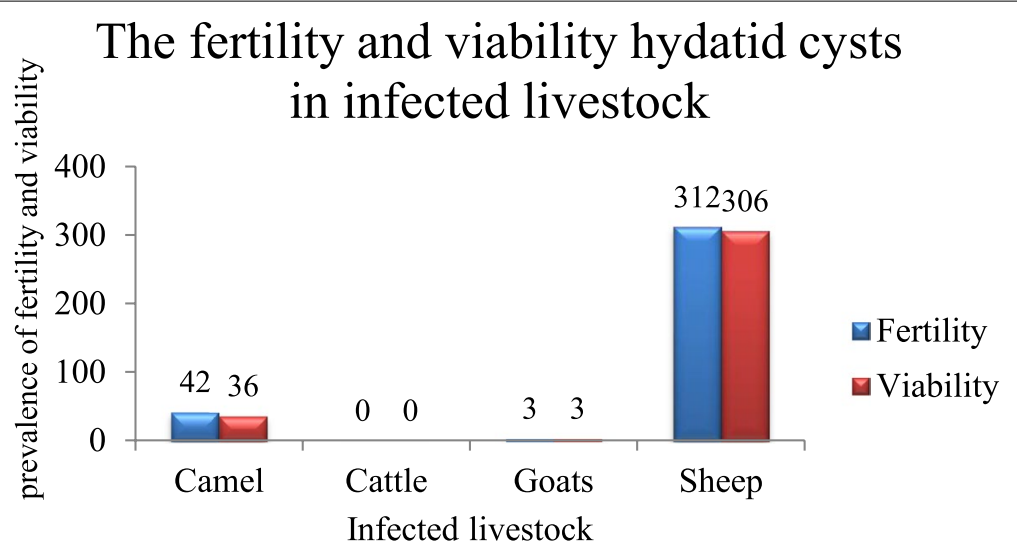

Fig. 4 The fertility and viability of Echinoccus granulosus s.l. cysts per slaughtered livestock

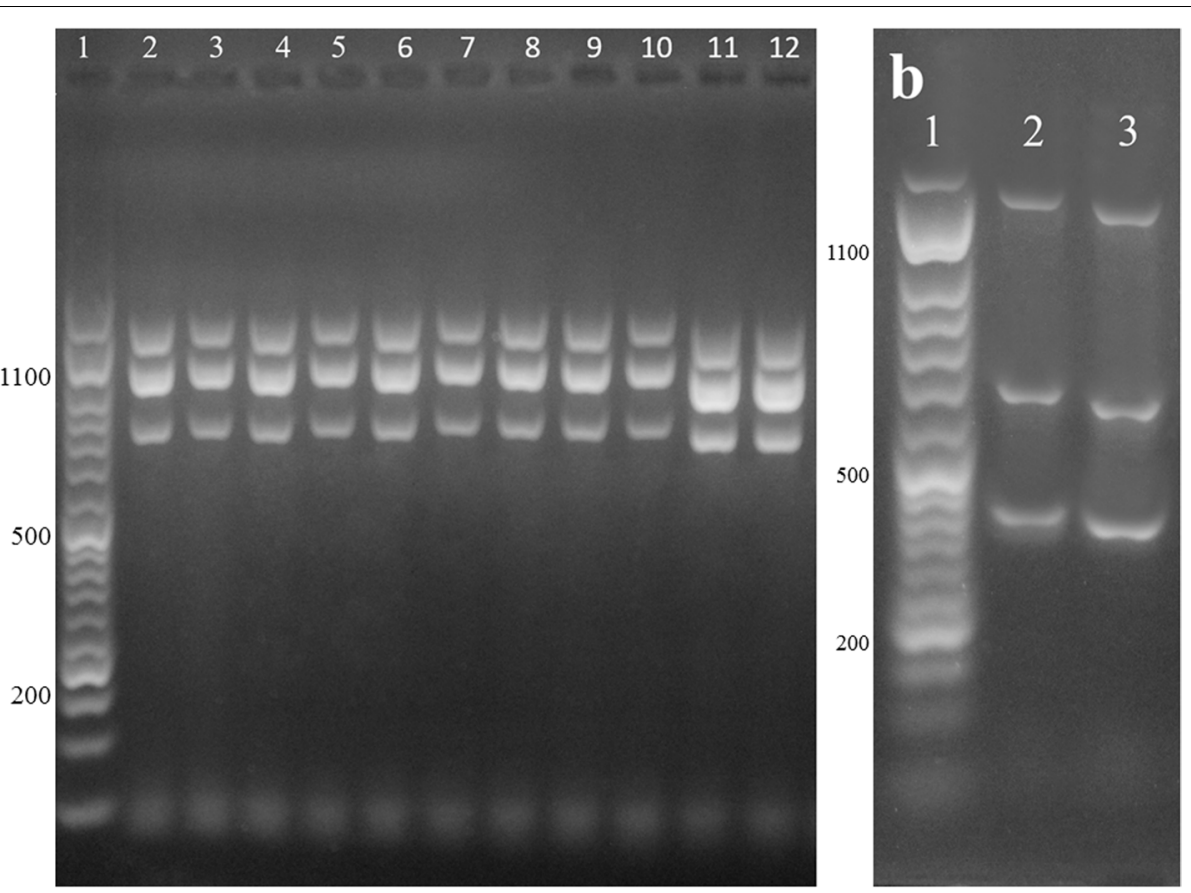

Fig. 5 Agarose gel electrophoresis of multiplex PCR analysis. a Lane 1:50 bp DNA ladder, lanes 2-12: G1-G3 genotypes. b Lane 1:50 bp DNA ladder, lanes 2-3: G6/G7 genotypes. The fragments of 1232 bp is specific for the Echinococcus genus. The bands with the size of 1001 and 706 are related to G1-G3 gentotypes; the fragments of 617 and 339 bp are corresponding to G6/G7 genotypes

groups concerning the infection rate $(p=0.00001)$. The location of hydatid cysts in animals differed, with $46.1 \%$ in the liver and $53.9 \%$ in the lung. The analysis revealed statistical significance between infection rate and cyst location in animals $(p=0.000011)$. We showed that $54.3 \%$ of hydatid cysts in animals were fertile, of which $87.4 \%$ were regarding cysts in sheep, following $11.7 \%$ in camels and $0.9 \%$ in goats. Among the fertile cysts, $96.6 \%$ were viable after staining with eosin $0.1 \%$, of which $88.7 \%$ were related to sheep, $10.4 \%$ to camels, and $0.9 \%$ to goats. Statistical analysis showed a significant relationship between viability and fertility with animal kinds $(p=0.00001)$.

\section{Molecular detection}

Out of 657 hydatid cysts, 164 isolates were randomly selected and assessed for molecular genotyping using multiplex PCR (Fig. 5). Finally, out of 164 isolates, 59 were randomly selected for sequencing, and they were amplified by PCR using the specific primer pair of the 
gene target of cytochrome c oxidase subunit 1 ( $\operatorname{cox} 1)$ resulted in the size of the amplicon of $450 \mathrm{bp}$ in length (Fig. 6). The sequences were submitted to NCBI, GenBank (Table 1).

The genotyping of the 164 samples showed that one isolate was Taenia hydatigena. The remaining $163 \mathrm{sam}-$ ples were $82.8 \%(135 / 163)$ G1-G3 genotypes, including $58.5 \%(79 / 135)$ in sheep, $24.5 \%(33 / 135)$ in camels, $12.6 \%(17 / 135)$ in cattle, and $4.4 \%(6 / 135)$ in goats; $11.7 \%(19 / 163)$ samples were G6/G7, including 52.7\% $(10 / 19)$ in camels, $21 \%(4 / 19)$ in sheep, $15.8 \%(3 / 19)$ in cattle, and $10.5 \%(2 / 19)$ in goats; and finally, $5.5 \%$ $(9 / 163)$ had G5 genotype, including $44.4 \%$ (4/9) in camels, $44.4 \%(4 / 9)$ in cattle, and $11.2 \%$ (1/9) in goats. Sequence analysis showed that among $E$. granulosus s.s. identified in this study, two isolates were identified only as G3 that were in sheep lung. No G5 genotype was found in sheep.

Out of 135 hydatid cysts with G1-G3 genotypes, $54.1 \%(73 / 135)$ samples were in the lung and $45.9 \%$ $(62 / 135)$ were in the liver. The G6/G7 genotype cysts were in the lung and liver, with the rate of $78.9 \%(15 / 19)$ and $21.1 \%(4 / 19)$, respectively. The cysts with the genotype of G5 were in the lung and liver with the rate of $88.9 \%(8 / 9)$ and $11.1 \%(1 / 9)$, respectively. The distribution of the different genotypes was variously based on the location of each animal (Table 2); however, the cyst location in each animal had no significant relationship with genotypes.

Regarding fertility and genotypes, $50.1 \%(73 / 135)$ of animal cysts with G1-G3 genotypes were fertile, of which 95.9\% (70/73) had viability. The fertility rate for G6/G7 genotype was $31.6 \%(6 / 19)$, of which $83.3 \%(5 / 6)$ had viability. In G5 hydatid cysts, $15.8 \%$ (3/19) were fertile, of which $66.7 \%$ (2/3) had viability. Regarding chi-square statistics with $p=0.002562$, the fertility rate is significantly concerning genotypes. The viability rate was related to genotypes $(p=0.034222)$.

\section{Phylogeny analysis}

In the Maximum Likelihood (ML) consensus tree obtained, all the specimens here analyzed clustered together with G1-G3 reference strains, demonstrating the circulation of the E. granulosus s.s. in the area (Fig. 7).

\section{Discussion}

In this study, 657 hydatid cyst samples were isolated from 63 sheep, 18 camels, 12 cattle, and 4 goats. In 97 infected animals, $73(75.3 \%)$ were females, even though the prevalence of infection was different in animal species $(p=0.00001)$. A higher prevalence in females was also described in several studies [16-23]. Female animals are at higher risk of $\mathrm{CE}$ infection because females are kept longer for milk production and reproductive functions [18]. In addition, females are raised near houses for milking, making them more exposed to infected dogs [19]. The relationship between age and the infected animals was significant in this study $(p=0.00001)$. The infection rate was high in animals aged between 1 and 5 years, except for camels where high infection rates were seen in animals older than 5 years. The increasing prevalence rate with age is in agreement with other studies carried out in several countries $[9,17-19,24-30]$. The causes of infection in older animals are longer duration of exposure and more time for cysts to grow in size for better diagnosis [18]. The cyst develops in camels after the age of 3 [31]. Therefore, we showed that the infection rate is related to the sex and age of animals. All cysts from infected animals were isolated from the lung and liver. We presented that the cyst location had a significant relationship with the infected animal species. Some other results from different studies also show a vast distribution of the cyst in animal organs. Azami et al. [16] reported that the highest and lowest cysts were in sheep lungs (27.1\%) and goat liver (11.6\%), respectively. In Pakistan, Ehsan et al. [18] demonstrated cysts in cattle, with $8.65 \%$ in the liver and $4.80 \%$ in the lung. Haleem et al. [19] reported that in Pakistan, the prevalence of hydatid cysts in the liver and lung was 63.49 and $23.80 \%$, respectively, including 69 cattle livers, 9 cattle lungs, 12 sheep livers, 14 sheep lungs, 3 goat livers, and 1 goat lung [19]. In another study in Pakistan, hydatid cysts were distributed in the liver and lung of various animals, including sheep with $67.81 \%$ in liver and $32.19 \%$ in lung, goats with $66.18 \%$ in liver and 32.60 in the lung, cattle with $84.51 \%$ in liver and $15.48 \%$ in lung, and camels with $83.33 \%$ in liver and $16.66 \%$ in the lung [32]. In the other study in Pakistan, the infection rates were $46.74 \%$ in sheep liver, $23.28 \%$ in goat liver, $17.37 \%$ in sheep lung, and $13.68 \%$ in goat lung [33]. Singh et al. [34] reported liver and lung infection rates with 49.66 and $36.179 \%$, respectively, in India's cattle, buffaloes, sheep, and goats. Elmajdoub and Rahman [35] in Libya demonstrated that among 372 samples in different organs, including 135 sheep livers, 105 sheep lungs, 28 camel livers, 64 camel lungs, 6 cattle livers, and 6 lung cattle. In a study carried out in north Ethiopia, hydatid cysts in cattle were $13 \%$ in the lung and $8.1 \%$ in the liver [36]. The organs' involvement is because passing the oncosphere is carried out via portal vein flow into the liver and other organs [37].

A high fertility rate was observed in cysts isolated from sheep, followed by goats and camels. No fertility was reported in the samples from cattle. The fertility rate of hydatid cysts was higher in the liver of sheep, whereas in camels and goat, fertile cysts were mostly found in lungs. 


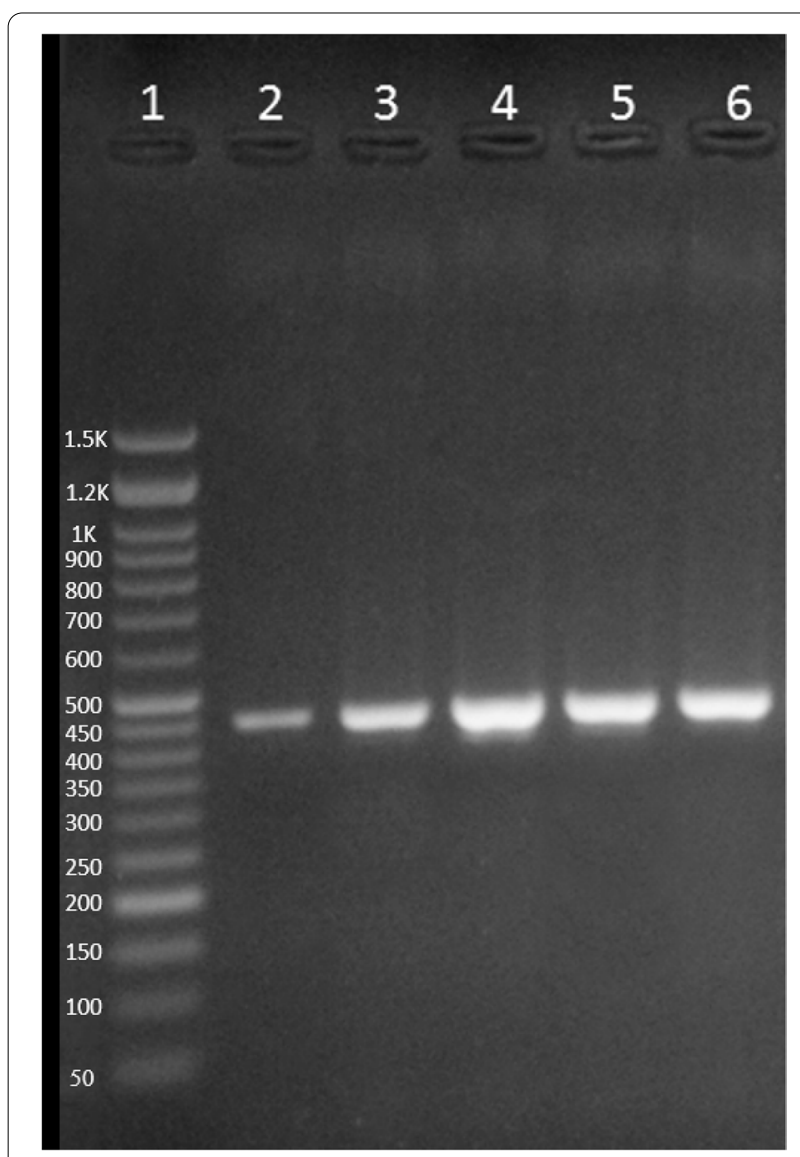

Fig. 6 Agarose gel electrophoresis for cox 1 amplification analysis. Lane 1: 50 bp DNA ladder, lanes 2-6: amplified cox 1 region in the samples. The expected amplicon size is $450 \mathrm{bp}$ in length

Some studies have reported more fertility in the liver $[16,20,38-40]$, and some studies reported more fertility in the lung [41-44]. In this study, it was found that none of the cysts from the cattle were fertile. This result is in agreement with some other studies $[30,45,46]$. No fertility in the hydatid cysts of the cattle reveals that this intermediate host would not be considered suitable, and therefore, cattle are a dead-end host [47]. Hence, understanding the fertility and viability of the hydatid cysts in the intermediate host is critical because livestock play as the main source of infection transmission of the final host by consuming fertile cysts. The fertility of the hydatid cyst is different in various geographical situations, animal species, locations, size, and genotype of the cyst [48]. There are many reports about the infertility rate of the hydatid cysts in various genotypes and animal species in different regions [36, 49], indicating that fertility depends on the genotype. The fertility rate may be different in various hosts due to the immunological response in the hosts [50]. In our study, high rate of cyst viability was observed in sheep, goats, and camel, in agreement with other studies $[16,19,51]$.

This study was the first molecular detection and identification of E. granulosus s.l. in slaughtered livestock in a desert area in Central Iran. However, more molecular epidemiological studies have been done on hydatid cysts in intermediate hosts in some other areas of Iran [8]. The only limitation in this study is that the molecular characterization was not performed on all hydatid cysts. Genotyping analysis in this study showed that E. granulosus s.l. G1-G3 genotypes were the most frequent in this area in all animals.

Out of 135 isolates belonging to E. granulosus s.s. (G1G3), $58.5 \%$ (79/135) were found in sheep, $24.5 \%(33 / 135)$ in camels, $12.6 \%(17 / 135)$ in cattle, and $4.4 \%(6 / 135)$ in goats. Among E. granulosus s.s. identified in this study, two isolates were identified only as G3. This result agrees with other studies conducted in different regions of Iran [52-59]. Sharbatkhori et al. [60] reported 78.3\% G1 genotype among hydatid cysts obtained from livestock in Golestan Province. Pezeshki et al. [61] also claimed 92\% G1 in the hydatid cysts isolated from domestic animals in Ardabil Province, northwestern Iran. Whereas, Nematdoost et al. [62] reported $7.2 \%$ G3 genotype in hydatid cysts collected from livestock. Some studies have also reported G3 genotype in Iran and other countries [56, 57, 59, 60, 63-67]. Also, among E. granulosus s.l., E. canadensis (G6/G7) and E. ortleppi (G5) were reported in slaughtered livestock with a prevalence of 11.7 and 5.5\%, respectively. From 19 isolates belonging to E. canadensis (G6/G7), 52.7\% (10/19) were found in camels, $21 \%(4 / 19)$ in sheep, $10.5 \%(2 / 19)$ in goats, and $15.8 \%(3 / 19)$ in cattle. Thus, it seems that cattle, camels, sheep, and goats are involved in the life cycle in Iran. In addition, there are some reports from different livestock worldwide. Rajabloo et al. [68] reported the G6 genotype in goats in Iran. Kesik et al. [69] reported one sample with the G6 genotype obtained from a camel in Turkey. There are also some reports of G6 genotype in goat in Argentina [70, 71]. The main intermediate host for the G6 genotype is the camel. However, it seems that camels living with other livestock may expose to other genotypes through interaction with dogs as definitive hosts living near them. There are some reports of G6 in humans worldwide. The first report of $E$. Canadensis (G6/G7) in humans found in Pakistan shows the importance of this genotype in clinical aspects [72], even though it was thought that the G6 genotype might be less infective to humans [73]. However, it is considered as the second most important causative agent of CE after E. granulosus s.s [74]. In South America, Africa, and Asia; E. granulosus s.l. G6 genotype infects humans [73]. Simsek and Kaplan [75] also reported two cases of human infection with the G6 genotype in Turkey. 
Table 1 The sequences used in the study

\begin{tabular}{|c|c|}
\hline Accession Number & Description \\
\hline MW553931 (G1) & Echinococcus granulosus isolate S1 K1 cytochrome c oxidase subunit I (COX1) gene \\
\hline MW724484 (G1) & Echinococcus granulosus isolate S1K2 cytochrome c oxidase subunit I (COX1) gene \\
\hline MW724481 (G1) & Echinococcus granulosus isolate S2K11 cytochrome c oxidase subunit I (COX1) gene \\
\hline MW509612 (G1) & Echinococcus granulosus isolate S1 k3 cytochrome c oxidase subunit I (COX1) gene \\
\hline MW674790 (G1) & Echinococcus granulosus isolate S1 K4 cytochrome c oxidase subunit I (COX1) gene \\
\hline MW509613 (G1) & Echinococcus granulosus isolate $\mathrm{S} 2 \mathrm{~K} 1$ cytochrome coxidase subunit I (COX1) gene \\
\hline MW665457 (G1) & Echinococcus granulosus isolate S2K3 cytochrome c oxidase subunit I (COX1) gene \\
\hline MW666055 & Taenia hydatigena isolate S3K1 cytochrome c oxidase subunit I (COX1) gene \\
\hline MW571043 (G1) & Echinococcus granulosus isolate S4R1 cytochrome c oxidase subunit I (COX1) gene \\
\hline MW672137 (G1) & Echinococcus granulosus isolate S6R2 cytochrome c oxidase subunit I (COX1) gene \\
\hline MW666181 (G1) & Echinococcus granulosus isolate S6R3 cytochrome c oxidase subunit I (COX1) gene \\
\hline MW672197 (G1) & Echinococcus granulosus isolate S6R10 cytochrome c oxidase subunit I (COX1) gene \\
\hline MW666108 (G1) & Echinococcus granulosus isolate S7K3 cytochrome coxidase subunit I (COX1) gene \\
\hline MW676786 (G1) & Echinococcus granulosus isolate S7K5 cytochrome c oxidase subunit I (COX1) gene \\
\hline MW567930 (G1) & Echinococcus granulosus isolate S7K6 cytochrome c oxidase subunit I (COX1) gene \\
\hline MW898297 (G1) & Echinococcus granulosus isolate S9R2 cytochrome c oxidase subunit I (COX1) gene \\
\hline MW724480 (G1) & Echinococcus granulosus isolate S10R1 cytochrome c oxidase subunit I (COX1) gene \\
\hline MW672209 (G3) & Echinococcus granulosus isolate S16R1 cytochrome c oxidase subunit I (COX1) gene \\
\hline MW563951 (G1) & Echinococcus granulosus isolate S18R1 cytochrome c oxidase subunit I (COX1) gene \\
\hline MW563953 (G1) & Echinococcus granulosus isolate S19R3 cytochrome c oxidase subunit I (COX1) gene \\
\hline MW563946 (G3) & Echinococcus granulosus isolate S23R1 cytochrome c oxidase subunit I (COX1) gene \\
\hline MW564021 (G1) & Echinococcus granulosus isolate S24R2 cytochrome c oxidase subunit I (COX1) gene \\
\hline MW564030 (G1) & Echinococcus granulosus isolate S26R1 cytochrome c oxidase subunit I (COX1) gene \\
\hline MW564032 (G1) & Echinococcus granulosus isolate $\mathrm{S} 31 \mathrm{~K} 1$ cytochrome coxidase subunit I (COX1) gene \\
\hline MW898298 (G1) & Echinococcus granulosus isolate $\mathrm{S} 34 \mathrm{~K} 1$ cytochrome c oxidase subunit I (COX1) gene \\
\hline MW564076 (G1) & Echinococcus granulosus isolate S38K1 cytochrome c oxidase subunit I (COX1) gene \\
\hline MW564079 (G1) & Echinococcus granulosus isolate $\mathrm{S} 39 \mathrm{~K} 1$ cytochrome coxidase subunit I (COX1) gene \\
\hline MW566585 (G1) & Echinococcus granulosus isolate $\mathrm{S} 40 \mathrm{~K} 1$ cytochrome coxidase subunit I (COX1) gene \\
\hline MW564207 (G1) & Echinococcus granulosus isolate S41R1 cytochrome c oxidase subunit I (COX1) gene \\
\hline MW566168 (G1) & Echinococcus granulosus isolate $\mathrm{S} 42 \mathrm{~K} 2$ cytochrome c oxidase subunit I (COX1) gene \\
\hline MW666128 (G1) & Echinococcus granulosus isolate S43K1 cytochrome c oxidase subunit I (COX1) gene \\
\hline MW567458 (G1) & Echinococcus granulosus isolate S48R1 cytochrome c oxidase subunit I (COX1) gene \\
\hline MW724526 (G1) & Echinococcus granulosus isolate S51 K2 cytochrome c oxidase subunit I (COX1) gene \\
\hline MW672317 (G1) & Echinococcus granulosus isolate $552 \mathrm{~K} 1$ cytochrome c oxidase subunit I (COX1) gene \\
\hline MW566173 (G1) & Echinococcus granulosus isolate S56K1 cytochrome c oxidase subunit I (COX1) gene \\
\hline MW666180 (G1) & Echinococcus granulosus isolate S57K2 cytochrome c oxidase subunit I (COX1) gene \\
\hline MW683516 (G1) & Echinococcus granulosus isolate B4K1 cytochrome c oxidase subunit I (COX1) gene \\
\hline MW683965 (G1) & Echinococcus granulosus isolate B5K2 cytochrome c oxidase subunit I (COX1) gene \\
\hline MW509614 (G1) & Echinococcus granulosus isolate B5k6 cytochrome c oxidase subunit I (COX1) gene \\
\hline MW567466 (G1) & Echinococcus granulosus isolate B7R1 cytochrome c oxidase subunit I (COX1) gene \\
\hline MW567290 (G5) & Echinococcus granulosus isolate B7R3 cytochrome c oxidase subunit I (COXI) gene \\
\hline MW567132 (G1) & Echinococcus granulosus isolate B7R5 cytochrome c oxidase subunit I (COX1) gene \\
\hline MW567286 (G1) & Echinococcus granulosus isolate B8R3 cytochrome c oxidase subunit I (COX1) gene \\
\hline MW665388 (G1) & Echinococcus granulosus isolate B8R4 cytochrome c oxidase subunit I (COX1) gene \\
\hline MW546059 (G5) & Echinococcus granulosus isolate $C 2 R 3$ cytochrome c oxidase subunit I (COXI) gene \\
\hline MW665386 (G1) & Echinococcus granulosus isolate $\mathrm{C} 3 \mathrm{~K} 2$ cytochrome c oxidase subunit I (COX1) gene \\
\hline MW546060 (G1) & Echinococcus granulosus isolate C3R2 cytochrome c oxidase subunit I (COX1) gene \\
\hline MW665389 (G1) & Echinococcus granulosus isolate $\mathrm{C} 3 \mathrm{~K} 5$ cytochrome c oxidase subunit I (COX1) gene \\
\hline MW549013 (G6) & Echinococcus granulosus isolate C3R5 cytochrome c oxidase subunit I (COX1) gene \\
\hline
\end{tabular}


Table 1 (continued)

\begin{tabular}{|c|c|}
\hline Accession Number & Description \\
\hline MW549010 (G5) & Echinococcus granulosus isolate C3R7 cytochrome c oxidase subunit I (COX1) gene \\
\hline MW665390 (G5) & Echinococcus granulosus isolate C3R9 cytochrome c oxidase subunit I (COX1) gene \\
\hline MW671557 (G1) & Echinococcus granulosus isolate $\mathrm{C} 4 \mathrm{~K} 1$ cytochrome c oxidase subunit I (COX1) gene \\
\hline MW665387 (G5) & Echinococcus granulosus isolate C4R7 cytochrome c oxidase subunit I (COX1) gene \\
\hline MW567459 (G6) & Echinococcus granulosus isolate G2R1 cytochrome coxidase subunit I (COX1) gene \\
\hline MW549002 (G1) & Echinococcus granulosus isolate G3R1 cytochrome c oxidase subunit I (COX1) gene \\
\hline MW549003 (G6/G7) & Echinococcus granulosus isolate G3R2 cytochrome c oxidase subunit I (COX1) gene \\
\hline MW549009 (G1) & Echinococcus granulosus isolate G3K3 cytochrome c oxidase subunit I (COX1) gene \\
\hline MW676785 (G1) & Echinococcus granulosus isolate G4R1 cytochrome c oxidase subunit I (COX1) gene \\
\hline MW564020 (G1) & Echinococcus granulosus isolate G4R3 cytochrome c oxidase subunit I (COX1) gene \\
\hline \multicolumn{2}{|l|}{ Reference } \\
\hline NC_038228.1 & Echinococcus granulosus sensu lato genotype G7 isolate 27 mitochondrion, complete genome \\
\hline NC_038227.1 & Echinococcus granulosus sensu lato genotype G6 isolate 1 mitochondrion, complete genome \\
\hline NC 011122.1 & Echinococcus ortleppi mitochondrion, complete genome \\
\hline NC_044548.1 & Echinococcus granulosus mitochondrion, complete genome \\
\hline NC_021144.1 & Echinococcus felidis mitochondrial DNA, complete genome, sample code: EfelUganda \\
\hline NC_009462.1 & Echinococcus vogeli mitochondrion, complete genome \\
\hline NC_009460.1 & Echinococcus shiquicus mitochondrion, complete genome \\
\hline NC_009461.1 & Echinococcus oligarthrus mitochondrion, complete genome \\
\hline NC_000928.2 & Echinococcus multilocularis mitochondrion, complete genome \\
\hline NC_020374.1 & Echinococcus equinus mitochondrion, complete genome \\
\hline GQ228819.1 & Taenia hydatigena mitochondrion, complete genome \\
\hline
\end{tabular}

E. ortleppi (G5) was not reported from sheep, but it was identified from nine cysts, one belonging to goats $(11.2 \%)$, four to camels $(44.4 \%)$, and four to cattle $(44.4 \%)$. This result is consistent with other studies done in different regions of Iran [52-58]. As mentioned above, E. ortleppi (G5) was reported in 5.5\% $(9 / 163)$ of E. granulosus s.l. cysts from goats, camels, and cattle that is less than the study by Nematdoost et al. [62] reported G5 in 5/45 (11.1\%) of cattle. Some other studies reported G5 genotype in buffaloes [76], goats [77], and camels [77-79]. Moreover, some

Table 2 The distribution of the different genotypes based on the cyst location of each cyst

\begin{tabular}{lllll}
\hline & \multicolumn{2}{l}{ Genotypes } & & \\
\cline { 2 - 4 } & G1-G3 & G6/G7 & G5 & P-value \\
\hline Camel lung & 23 & 8 & 4 & $>0.05$ \\
Camel liver & 10 & 2 & 0 & \\
Sheep liver & 41 & 1 & 0 & $>0.05$ \\
Sheep lung & 38 & 3 & 0 & \\
Goat lung & 4 & 2 & 0 & $>0.05$ \\
Goat liver & 2 & 0 & 1 & \\
Cattle lung & 8 & 2 & 4 & $>0.05$ \\
Cattle liver & 9 & 1 & 0 & \\
\hline
\end{tabular}

studies reported G5 genotype in sheep [77, 80] that is opposite to our results. In this study, $75 \%(3 / 4)$ of hydatid cysts found in camels with G5 genotype were fertile, whereas G5 in goats and cattle were infertile. The result concerning the G5 genotype showing no fertility in cattle agrees with the study conducted in Pakistan [81]. However, Monteiro et al. [82] reported the frequency of $43.4 \%$ G5 genotype for fertile cysts in the lung of cattle in Brazil.

\section{Conclusions}

To the best of our knowledge, the molecular identification of hydatid cysts was performed for the first time in the livestock slaughtered in Central Iran. The genotypes of G1-G3 and G6/G7 exist in all livestock being studied, but G5 was reported only in cattle, goats, and camels. Therefore, the dominant genotypes in Central Iran are G1-G3 and then G6/G7, which should be considered a high-priority public health concern.

\section{Methods}

In this study, 97 slaughtered animals with echinococcosis from Yazd abattoir were included to assess the variables of sex, age, cyst location, fertility, viability of 


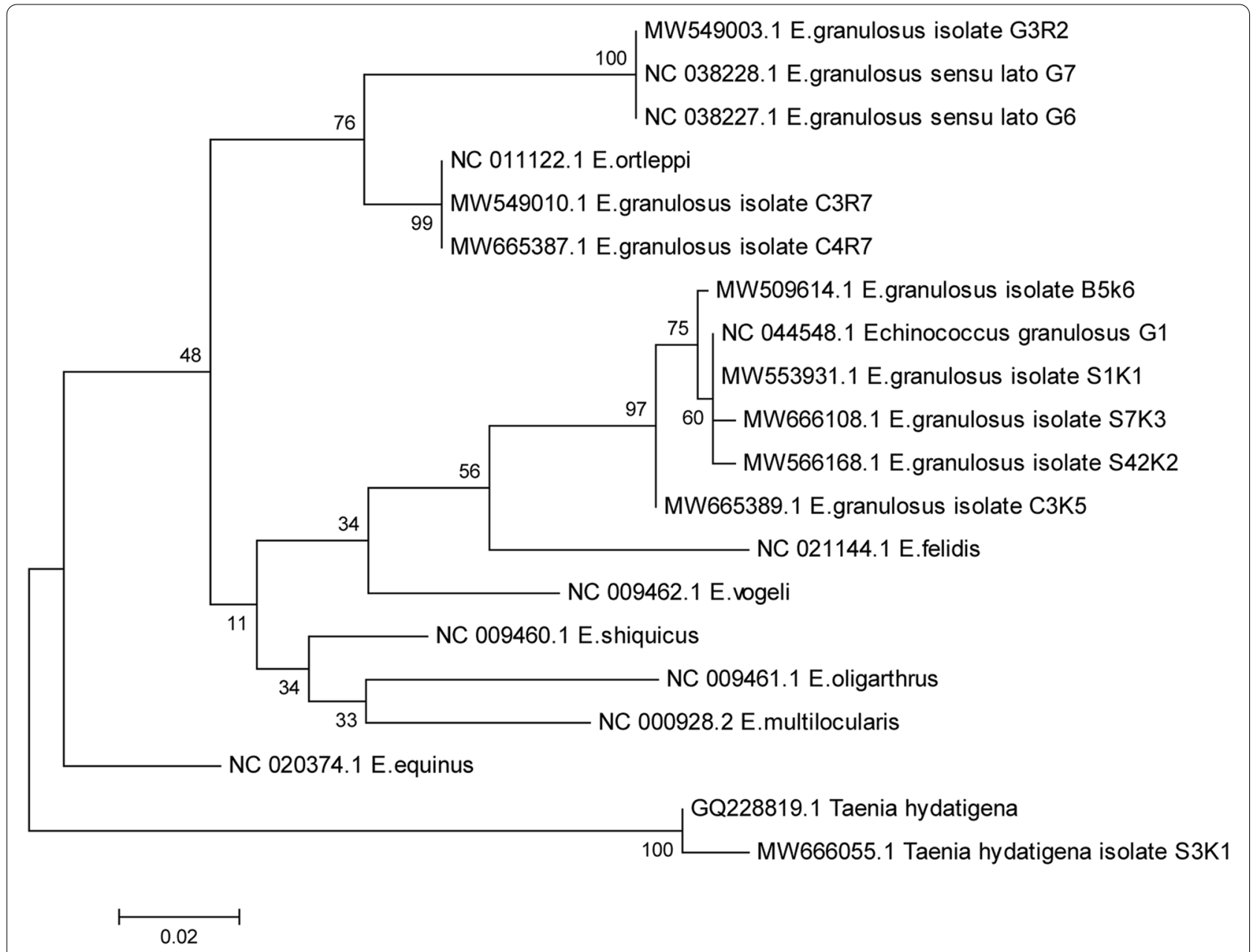

Fig. 7 Molecular phylogenetic analysis of Echinococcus granulosus isolates based on cox 1 sequences. The evolutionary history was inferred by using the Maximum Likelihood method based on the Tamura-Nei model. The analysis involved 20 nucleotide sequences. All positions containing gaps and missing data were eliminated. Evolutionary analyses were conducted in MEGAX

protoscoleces, and genotyping. In this study, we used the discarded organs with hydatid cysts.

\section{Ethical approval}

All experiments were ethically performed following standard protocols approved by the Ethics Committee of Shahid Sadoughi University of Medical Sciences, Yazd, Iran (Approval ID: IR. SSU. SPH.REC. 1398.068).

\section{Sample collection}

In the current study, 657 hydatid cysts were isolated from 63 sheep, 12 cattle, 18 camels, and 4 goats, comprising 434 samples from sheep, 118 samples from cattle, 13 samples from goats, and 92 from camels from September 2018 to January 2020 from slaughtered animals during post-mortem inspection from an abattoir in Yazd Province, Central Iran. Collected cysts from lungs and livers were transported to the
Research Center of Food Hygiene and Safety, Shahid Sadoughi University of Medical Sciences, Yazd, Iran. The sex and age of each animal were recorded by a veterinarian in the slaughterhouse. The eruption of permanent incisor teeth was the main criteria used to determine the age of the animals [83].

\section{Viability and fertility}

After sterilizing the cyst surface with $70 \%$ alcohol, the cyst fluid was aspirated and centrifuged at $500 \mathrm{xg}$ for $60 \mathrm{~s}$. For fertility assessment, the pellet was analyzed for protoscoleces present using a light microscope. Cysts without any protoscoleces were detected as sterile. The viability of the protoscoleces was evaluated using $0.1 \%$ eosin staining. The nonviable protoscoleces were stained in red. 


\section{DNA extraction}

Protoscoleces (if presented) and germ layers were used for genotype analysis. The protoscoleces were washed with phosphate-buffered solution (PBS) in triplicate. According to the manufacturer's instructions, the genomic DNA (gDNA) was extracted using a Tissue DNA Extraction Kit (GeneAll, South Korea). The quantity of the extracted DNA samples was analyzed using a NanoDrop device (Thermo Fisher Scientific, Massachusetts, USA) and stored at $-20^{\circ} \mathrm{C}$ until the next analysis.

\section{Molecular detection}

Characteristics of primers used for multiplex PCR are shown in Table 3. PCR reaction was conducted in a $50 \mu \mathrm{l}$ final volume containing $50-100 \mathrm{ng}$ of gDNA, $0.2 \mathrm{mM}$ dNTPs, $2 \mathrm{mM} \mathrm{MgCl}_{2}$, and different concentrations of each primer are described in Tables 3, $1.5 \mathrm{U}$ of Taq DNA polymerase, and sterile $\mathrm{ddH}_{2} \mathrm{O}$ up the final volume. The cycling conditions were as follows: an initial denaturation step at $94{ }^{\circ} \mathrm{C}$ for $3 \mathrm{~min}$; 30 cycles of $94^{\circ} \mathrm{C}$ for $30 \mathrm{~s}, 56^{\circ} \mathrm{C}$ for $30 \mathrm{~s}, 72^{\circ} \mathrm{C}$ for $1 \mathrm{~min}$; and a final extension for $5 \mathrm{~min}$ at $72^{\circ} \mathrm{C}$ [84]. The PCR products were assessed in $2 \%$ agarose gel electrophoresis (Akhtarian, Tehran, Iran) alongside with $50 \mathrm{bp}$ DNA ladder (GenRuler, Thermo Fisher Scientific, USA, CA). To detect DNA fragments, DNA Green Viewer (Pars Tous, Iran, Mashhad) was applied. Then, visualization was done under UV light using Gel Documentation (ATP, Iran, Tehran).

\section{Sequencing}

To verify the multiplex PCR resulting from genotyping, 59 samples were selected to sequence the gene target of cox 1 randomly from the cysts obtained from all various species of animals. The PCR reaction was conducted using a thermal cycler (ABI, USA) in a $20 \mu \mathrm{l}$ final volume containing 50-100 ng gDNA, $0.2 \mathrm{mM}$ dNTPs (Ampliqon, Denmark), $1.5 \mathrm{mM} \mathrm{MgCl}_{2}$ (Ampliqon, Denmark), 10 pmol of each primer (ordered from Pishgam Company), $1.5 \mathrm{U}$ Taq DNA polymerase, and $\mathrm{dd}_{2} \mathrm{O}$ up to the final volume. Amplification was done using the specific primer pair for cox 1 by JB3: $5^{\prime}$-TTTTTTGGG CATCCTGAGGTTTAT- $3^{\prime}$ and JB4.5: $5^{\prime}$-TAAAGAAAG AACATAATGAAAATG-3' [84] resulted in an amplicon fragment of $450 \mathrm{bp}$ in length. The temperature conditions were an initial denaturation at $94^{\circ} \mathrm{C}$ for $5 \mathrm{~min}$; then 35 cycles of denaturation at $94^{\circ} \mathrm{C}$ for $45 \mathrm{~s}$, annealing at $57^{\circ} \mathrm{C}$ for $45 \mathrm{~s}$, and elongation at $72^{\circ} \mathrm{C}$ for $45 \mathrm{~s}$. The final extension was done at $72^{\circ} \mathrm{C}$ for $5 \mathrm{~min}$. PCR products were detected in $1 \%$ agarose gel electrophoresis (Akhtarian, Tehran, Iran). The PCR product was excised
Table 3 Characteristics of oligonucleotides used for Echinococcus granulosus s.l. complex multiplex PCR [84]

\begin{tabular}{|c|c|c|c|}
\hline Primer name & $\begin{array}{l}\text { End } \\
\text { concentration } \\
(\mu \mathrm{M})\end{array}$ & Sequence $\left(5^{\prime}-3^{\prime}\right)$ & $\begin{array}{l}\text { Product } \\
\text { size (bp) }\end{array}$ \\
\hline Echi Rpb2 F & 1 & $\begin{array}{l}\text { TTGACCAAAGAAATC } \\
\text { AGAC }\end{array}$ & 1232 \\
\hline Echi Rpb2 R & 1 & CGCAAATACTCCATGG & \\
\hline E.g complex F & 0.15 & $\begin{array}{l}\text { TGGTCGTCTTAATCA } \\
\text { TTTG }\end{array}$ & 110 \\
\hline E.g complex R & 0.15 & $\begin{array}{l}\text { CCACAACAATAGGCA } \\
\text { TAA }\end{array}$ & \\
\hline E.g ss cal F & 2 & $\begin{array}{l}\text { CAATTTACGGTAAAG } \\
\text { CAT }\end{array}$ & 1001 \\
\hline E.g ss cal R & 2 & ССТСАТСТССАСТСТСТ & \\
\hline E.g ss Ef1a F & 1 & $\begin{array}{l}\text { TCCTAACATGCCTTG } \\
\text { GTAT }\end{array}$ & 706 \\
\hline E.g ss Ef1a R & 1 & $\begin{array}{l}\text { GTTACAGCCTTGATC } \\
\text { ACG }\end{array}$ & \\
\hline E.eq cal F & 2 & GCTTATTTAGGATCCCA & 426 \\
\hline E.eq cal R & 2 & TCGTTTTTGCCAGTG & \\
\hline E.eq coxl F & 0.2 & GTTGGGTTGGATGTT & 124 \\
\hline E.eq coxl R & 0.2 & $\begin{array}{l}\text { CAAAACAGGATCACT } \\
\text { CTT }\end{array}$ & \\
\hline E.ortp ATP6 F & 0.05 & $\begin{array}{l}\text { GTGTCGTGTGTTTAG } \\
\text { TGAG }\end{array}$ & 1041 \\
\hline E.ortp ATP6 R & 0.05 & $\begin{array}{l}\text { GCACTGATACAGGTG } \\
\text { TTATT }\end{array}$ & \\
\hline E.ortp Coxl F & 0.2 & GGTTTTATGGGTTGTTA & 250 \\
\hline E.ortp Coxl R & 0.2 & ACACCACCAAACGTG & \\
\hline E.cnd $\mathrm{G} 6 / \mathrm{G} 7$ pold F & 1 & $\begin{array}{l}\text { GGCCTTCATCTCCAT } \\
\text { AATA }\end{array}$ & 617 \\
\hline E.cnd $\mathrm{G} 6 / \mathrm{G} 7$ pold $\mathrm{R}$ & 1 & $\begin{array}{l}\text { ATGAAGAGTTTGAAA } \\
\text { CTAAAG }\end{array}$ & \\
\hline E.cnd G6/G7 NDI F & 0.3 & CTGCAGAGGTTTGCC & 339 \\
\hline E.cnd G6/G7 NDI R & 0.3 & $\begin{array}{l}\text { CACAACAGCATA } \\
\text { AAGCG }\end{array}$ & \\
\hline E.cnd G8/G10 Elp F & 1.5 & $\begin{array}{l}\text { CCTAGTCTTCCCATG } \\
\text { ATA }\end{array}$ & 283 \\
\hline E.cnd G8/G10 Elp R & 1.5 & ACAGAAGGCATATCCA & \\
\hline
\end{tabular}

from agarose gel, and sent to the Company (Pishgam Company, Tehran, Iran) for purification and sequencing. The sequencing results were analyzed using BLAST.

\section{Phylogenetic analysis}

Sequence data of E. granulosus s.l. isolates were complete alignment using the T-COFFEE software [85]. Also haplotypes defined by combination of single nucleotide polymorphisms were assigned using DnaSP V.6. Phylogenetic analysis were inferred from DNA sequences using Maximum Likelihood (ML) estimates with MEGAX based on Tamura-Nei model with 1000 bootstrap replicates. 


\author{
All positions containing gaps and missing data were \\ eliminated.
}

\section{Statistical analysis}

The obtained data were analyzed using SPSS version 16.0. In the first step, the data were entered into the software. Then, descriptive data analysis was performed, including frequency and prevalence calculation. The relationship between infection in animals with sex, age, cyst location, and fertility, and viability of infected animal species were analyzed using the chi-square test. With confidence level of $95 \%$, P-value $<0.05$ was considered as significant.

\section{Abbreviations}

CE: Cystic echinococcosis; PBS: Phosphate-buffered salin; gDNA: Genomic DNA; ML: Maximum likelihood.

\section{Acknowledgments}

We would like to thank all who helped us to perform the study. This study was done by the Research Center of Food Hygiene and Safety, Shahid Sadoughi University of Medical Sciences, Yazd, Iran (ID No. 6739), and we sincerely thank the technical supports of the Research Center of Food Hygiene and Safety staff.

\section{Authors' contributions}

$\mathrm{BH}$ wrote and reviewed the manuscript and designed the methodology; $\mathrm{AD}$ conceptualized, wrote, reviewed, and edited the manuscript; GE designed the methodology, supervised, wrote and edited the original draft; SA applied the method and collected the data; SA applied the method and collected the data; SZ applied the method and collected the data; AB applied the method and collected the data; SSH supervised the methodology and performed the molecular methods; VA wrote the original draft of the manuscript; MS did the molecular methods; MNA supervised the data collection; MJB collected data; MJR did the methods; MV analyzed the data statistically. All authors read and approved this manuscript.

\section{Authors' information}

$\mathrm{BH}$, Associate Professor, is the Head of Department of Food Hygiene and Safety, School of Health, Shahid Sadoughi University of Medical Sciences, Yazd, Iran; $A D$, Professor, is the Head of Parasitology Department, Tarbiat Modares, Tehran, Iran; GE, Associate Professor, is the Head of Department of Parasitology and Mycology, School of Medicine; the Head of Research Center for Food Hygiene and Safety, School of Public Health, Shahid Sadoughi University of Medical Sciences, Yazd, Iran; SA, MSc, has graduated from Medical Parasitology; SZ is a MSc student of Medical Parasitology; AB is a MSc student of Food Hygiene and Safety; SSH is a MSc graduated of Medical Bacteriology and the supervisor of Laboratory in Research Center for Food Hygiene and Safety, School of Public Health, Shahid Sadoughi University of Medical Sciences, Yazd, Iran; VA is a MSc graduated from Medical Immunology and staff of the Research Center for Food Hygiene and Safety, School of Public Health, Shahid Sadoughi University of Medical Sciences, Yazd, Iran; MS is a MSc graduated from Medical Bacterology and staff of the Research Center for Food Hygiene and Safety, School of Public Health, Shahid Sadoughi University of Medical Sciences, Yazd, Iran; MNA, Doctor of Veterinary Medicine and Chief Health Officer; MJB is BS of Laboratory Sciences and staff of the Research Center for Food Hygiene and Safety, School of Public Health, Shahid Sadoughi University of Medical Sciences, Yazd; MJR is a MSc student of Medical Parasitology; MV, Associate Professor, the Head of the Department of Community and Preventive Medicine, School of Medicine, Shahid Sadoughi University of Medical Sciences, Yazd, Iran.

\section{Funding}

We would like to thank Iran National Science Foundation (Grant no. 97018792) for the financial support.

\section{Availability of data and materials}

The datasets used and analyzed during the current study are available from the corresponding author on reasonable request. All the sequences were deposited in the NCBI GenBank (https://www.ncbi.nlm.nih.gov).

\section{Declarations}

\section{Ethics approval and consent to participate}

The ethical statement of this study was approved and written by the Ethical Committee for Shahid Sadoughi University of Medical Sciences with the code of IR.SSU.SPH.REC.1398.085. All methods were carried out in accordance with relevant guidelines and regulations. This project was approved by Shahid Sadoughi University of Medical Sciences, Yazd, Iran, by the code of 6739.

\section{Consent for publication}

Not applicable.

\section{Competing interests}

The authors declare that they have no competing interests.

\section{Author details}

${ }^{1}$ Research Center for Food Hygiene and Safety, Shahid Sadoughi University of Medical Sciences, Yazd, Iran. ${ }^{2}$ Department of Food Hygiene and Safety, School of Public Health, Shahid Sadoughi University of Medical Sciences, Yazd, Iran. ${ }^{3}$ Department of Parasitology, Faculty of Medical Sciences, Tarbiat Modares University, Tehran, Iran. ${ }^{4}$ Department of Parasitology and Mycology, School of Medicine, Shahid Sadoughi University of Medical Sciences, Yazd, Iran. ${ }^{5}$ Inspection of the Chief Health Officer (Meat Inspector), Yazd, Iran. ${ }^{6}$ Department of Community and Preventive Medicine, Health Monitoring Research Center, School of Medicine, Shahid Sadoughi University of Medical Sciences, Yazd, Iran.

Received: 10 July 2021 Accepted: 29 December 2021

Published online: 07 January 2022

References

1. Romig T, Deplazes P, Jenkins D, Giraudoux P, Massolo A, Craig PS, et al. Ecology and life cycle patterns of Echinococcus species. Adv Parasitol. 2017;95:213-314

2. Budke CM, Deplazes P, Torgerson PR. Global socioeconomic impact of cystic echinococcosis. Emerg Infect Dis. 2006;12:296-303.

3. Gessese AT. Review on epidemiology and public health significance of hydatidosis. Vet Med Int. 2020;2020:8859116.

4. Vuitton DA, McManus DP, Rogan MT, Romig T, Gottstein B, Naidich A et al. International consensus on terminology to be used in the field of echinococcoses. Parasite. 2020;27:41.

5. Kinkar L, Laurimäe T, Acosta-Jamett G, Andresiuk V, Balkaya I, Casulli A, et al. Global phylogeography and genetic diversity of the zoonotic tapeworm Echinococcus granulosus sensu stricto genotype G1. Int J Parasitol. 2018;48:729-42.

6. Hamiroune M, Dahmane M, Charef A, Cheniguel H, Foughalia H, Saidani $K$, et al. Evaluation of fascioliasis, hydatidosis, and tuberculosis in domestic animals during post-mortem inspection at Jijel slaughterhouse (Algeria). J Food Qual Hazards Control. 2020;7:149-56.

7. Grosso G, Gruttadauria S, Biondi A, Marventano S, Mistretta A. Worldwide epidemiology of liver hydatidosis including the Mediterranean area. World J Gastroenterol. 2012;18:1425-37.

8. Sharbatkhori M, Mirhendi H, Harandi MF, Rezaeian M, Mohebali M, Eshraghian M, et al. Echinococcus granulosus genotypes in livestock of Iran indicating high frequency of G1 genotype in camels. Exp Parasitol. 2010;124:373-9.

9. Rokni M. Echinococcosis/hydatidosis in Iran. Iran J Parasitol. 2009:4:1-16.

10. Razi Jalali M, Ahmadiara E, Rahimzade A, Shekarian M, Javidi Dasht-bayaz J, Jamshidi L, et al. Prevalence, fertility, and viability rates of hydatid cysts in surgical patients and slaughtered small ruminants in Ahvaz, southwest of Iran. J Food Qual Hazards Control. 2017:4:49-52. 
11. Shahbazi Y, Chalehchaleh A. Prevalence of common food-borne parasitic diseases in slaughtered ruminants in west part of Iran. J Food Qual Hazards Control. 2017:4:85-9.

12. Wu C, Zhang W, Ran B, Fan H, Wang H, Guo B, et al. Genetic variation of mitochondrial genes among Echinococcus multilocularis isolates collected in western China. Parasit Vectors. 2017;10:265.

13. Alvarez Rojas CA, Ebi D, Gauci CG, Scheerlinck JP, Wassermann M, Jenkins DJ, et al. Microdiversity of Echinococcus granulosus sensu stricto in Australia. Parasitology. 2016;143:1026-33.

14. Romig T, Ebi D, Wassermann M. Taxonomy and molecular epidemiology of Echinococcus granulosus sensu lato. Vet Parasitol. 2015;213:76-84.

15. Khademvatan S, Majidiani H, Foroutan M, Hazrati Tappeh K, Aryamand S, Khalkhali HR. Echinococcus granulosus genotypes in Iran: a systematic review. J Helminthol. 2019;93:131-8.

16. Azami M, Anvarinejad M, Ezatpour B, Alirezaei M. Prevalence of hydatidosis in slaughtered animals in Iran. Turkiye Parazitol Derg. 2013;37:102-6.

17. Beyhan YE, Umur \$̧. Molecular characterization and prevalence of cystic echinococcosis in slaughtered water buffaloes in Turkey. Vet Parasitol. 2011;181:174-9.

18. Ehsan M, Akhter N, Bhutto B, Arijo A, Gadahi JA. Prevalence and genotypic characterization of bovine Echinococcus granulosus isolates by using cytochrome oxidase 1 (Co1) gene in Hyderabad, Pakistan. Vet Parasitol. 2017;239:80-5

19. Haleem S, Niaz S, Qureshi NA, Ullah R, Alsaid MS, Alqahtani AS, et al. Incidence, risk factors, and epidemiology of cystic echinococcosis: a complex socioecological emerging infectious disease in Khyber Pakhtunkhwa, Province of Pakistan. Biomed Res Int. 2018;2018:5042430.

20. I labal H, Maqbool A, Lateef M, Khan M, Riaz A, Mahmood A, et al. Studies on hydatidosis in sheep and goats at Lahore, Pakista. J Anim Plant Sci. 2012;22:894-7.

21. Khan MA, Tanveer A, Younus M, Shafiq M, Saeed K, Ammara H, et al. Prevalence, organ specificity and economic impact of hydatidosis in the cattle slaughtered in the Lahore abattoir. IJAVMS. 2010:4:38-40.

22. Pour AA, Hosseini S, Shayan P. The prevalence and fertility of hydatid cysts in buffaloes from Iran. J Helminthol. 2012;86:373-7.

23. Salih M, Degefu H, Yohannes M. Infection rates, cyst fertility and larval viability of hydatid disease in camels (Camelus dromedarius) from Borena, Kereyu and Harar areas of Ethiopia. Glob Vet. 2011;7:518-22.

24. Azlaf R, Dakkak A. Epidemiological study of the cystic echinococcosis in Morocco. Vet Parasitol. 2006;137:83-93.

25. Capuano F, Rinaldi L, Maurelli M, Perugini A, Veneziano V, Garippa G, et al. Cystic echinococcosis in water buffaloes: epidemiological survey and molecular evidence of ovine (G1) and buffalo (G3) strains. Vet Parasitol. 2006;137:262-8.

26. Ibrahim MM, Ghamdi M, Gahmdi M. Helminths community of veterinary importance of livestock in relation to some ecological and biological factors. Turkiye Parazitol Derg. 2008;32:42-7.

27. Lahmar S, Kilani M, Torgerson P, Gemmell M. Echinococcus granulosus larvae in the livers of sheep in Tunisia: the effects of host age. Ann Trop Med Parasitol. 1999;93:75-81.

28. Regassa F, Molla A, Bekele J. Study on the prevalence of cystic hydatidosis and its economic significance in cattle slaughtered at Hawassa municipal abattoir, Ethiopia. Trop Anim Health Prod. 2010:42:977-84.

29. Rinaldi L, Maurelli M, Capuano F, Perugini A, Veneziano V, Cringoli S. Molecular update on cystic echinococcosis in cattle and water buffaloes of southern Italy. Zoonoses Public Health. 2008;55:119-23.

30. Varcasia A, Dessì G, Lattanzio S, Marongiu D, Cuccuru C, Carta S, et al. Cystic echinococcosis in the endemic island of Sardinia (Italy): has something changed? Parasitol Res. 2020;119:2207-15.

31. M'rad S, Filisetti D, Oudni M, Mekki M, Belguith M, Nouri A, et al. Molecular evidence of ovine (G1) and camel (G6) strains of Echinococcus granulosus in Tunisia and putative role of cattle in human contamination. Vet Parasitol. 2005;129:267-72.

32. Latif AA, Tanveer A, Maqbool A, Siddiqi N, Kyaw-Tanner M, Traub RJ. Morphological and molecular characterisation of Echinococcus granulosus in livestock and humans in Punjab, Pakistan. Vet Parasitol. 2010:170:44-9.

33. Sher Ahmed MN, Gul R, Zakir M, Razzaq A. Some epidemiological aspects of hydatidosis of lungs and livers of sheep and goats in Quetta, Pakistan. Pakistan J Zool. 2006;38:1-6.
34. Singh BB, Sharma JK, Tuli A, Sharma R, Bal MS, Aulakh RS, et al. Prevalence and morphological characterisation of Echinococcus granulosus from North India. J Parasit Dis. 2014;38:36-40.

35. Elmajdoub LO, Rahman WA. Prevalence of hydatid cysts in slaughtered animals from different areas of Libya. Open J Vet Med. 2015:5:1-10.

36. Kebede W, Hagos A, Girma Z, Lobago F. Echinococcosis/hydatidosis: its prevalence, economic and public health significance in Tigray region, North Ethiopia. Trop Anim Health Prod. 2009;41:865-71.

37. Pakala T, Molina M, Wu GY. Hepatic echinococcal cysts: a review. J Clin Transl Hepatol. 2016;4(1):39-46.

38. Daryani A, Alaei R, Arab R, Sharif M, Dehghan M, Ziaei H. The prevalence, intensity and viability of hydatid cysts in slaughtered animals in the Ardabil province of Northwest Iran. J Helminthol. 2007;81:13-7.

39. Macin S, Orsten S, Samadzade R, Colak B, Cebeci H, Fındık D. Human and animal cystic echinococcosis in Konya, Turkey: molecular identification and the first report of E. equinus from human host in Turkey. Parasitol Res. 2021;120:563-8.

40. Yildiz K, Gurcan S. Prevalence of hydatidosis and fertility of hydatid cysts in sheep in Kirikkale, Turkey. Acta Vet Hung. 2003;51:181-7.

41. Ahmadi N, Dalimi A. Characterization of Echinococcus granulosus isolates from human, sheep and camel in Iran. Infect Genet Evol. 2006;6:85-90.

42. Salem COA, Schneegans F, Chollet J, Et JM. Epidemiological studies on echinococcosis and characterization of human and livestock hydatid cysts in Mauritania. Iran J Parasitol. 2011;6:49-57.

43. Scala A, Garippa G, Varcasia A, Tranquillo V, Genchi C. Cystic echinococcosis in slaughtered sheep in Sardinia (Italy). Vet Parasitol. 2006;135:33-8.

44. Joanny G, Mehmood N, Dessì G, Tamponi C, Nonnis F, Hosri C, et al. Cystic echinococcosis in sheep and goats of Lebanon. Parasitology. 2021;148:871-8.

45. Mwambete KD, Ponce-Gordo F, Cuesta-Bandera C. Genetic identification and host range of the Spanish strains of Echinococcus granulosus. Acta Trop. 2004;91:87-93.

46. Umhang G, Richomme C, Boucher J-M, Hormaz V, Boué F. Prevalence survey and first molecular characterization of Echinococcus granulosus in France. Parasitol Res. 2013;112:1809-12.

47. Paredes R, Godoy P, Rodriguez B, Garcia MP, Cabezon C, Cabrera G, et al. Bovine (Bos taurus) humoral immune response against Echinococcus granulosus and hydatid cyst infertility. J Cell Biochem. 2011;112:189-99.

48. Fallah M, Kavand A, Yousefi MR. Infected hydatid cysts bacteria in slaughtered livestock and their effects on protoscoleces degeneration. Jundishapur J Microbiol. 2014;7:e10135. https://doi.org/10.5812/jjm.10135.

49. Khan A, El-Buni A, Ali M. Fertility of the cysts of Echinococcus granulosus in domestic herbivores from Benghazi, Libya, and the reactivity of antigens produced from them. Ann Trop Med Parasitol. 2001;95:337-42.

50. Hidalgo C, Stoore C, Strull K, Franco C, Corrêa F, Jiménez M, et al. New insights of the local immune response against both fertile and infertile hydatid cysts. PLoS One. 2019;14:e0211542.

51. Dalimi A, Motamedi G, Hosseini M, Mohammadian B, Malaki H, Ghamari Z, et al. Echinococcosis/hydatidosis in western Iran. Vet Parasitol. 2002;105:161-71.

52. Bowles J, Van Knapen F, Mcmanus D. Cattle strain of Echinococcus granulosus and human infection. Lancet (British Edition). 1992;339:1358.

53. Dybicz M, Borkowski PK, Jonas M, Wasiak D, Małkowski P. First report of Echinococcus ortleppi in human cases of cystic echinococcosis in Poland. Biomed Res Int. 2019;2019:2474839.

54. Bosco A, Alves LC, Cociancic P, Amadesi A, Pepe P, Morgoglione ME, et al. Epidemiology and spatial distribution of Echinococcus granulosus in sheep and goats slaughtered in a hyperendemic European Mediterranean area. Parasit Vectors. 2021;14:421.

55. Matini M, Fallah M, Maghsood AH, Saidijam M, Harandi MF. Echinococcus granulosus sensu stricto in livestock and human in Hamadan, Western Iran. Iran J Parasitol. 2019;14:288-96.

56. Nikmanesh B, Mirhendi H, Mahmoudi S, Rokni MB. Multilocus sequence analysis of Echinococcus granulosus strains isolated from humans and animals in Iran. Exp Parasitol. 2017:183:50-5.

57. Parsa F, Harandi MF, Rostami S, Sharbatkhori M. Genotyping Echinococcus granulosus from dogs from Western Iran. Exp Parasitol. 2012;132:308-12.

58. Sharbatkhori M, Mirhendi $H$, Jex AR, Pangasa A, Campbell BE, Kia EB, et al. Genetic categorization of Echinococcus granulosus from humans and 
herbivorous hosts in Iran using an integrated mutation scanning-phylogenetic approach. Electrophoresis. 2009;30:2648-55.

59. Sharbatkhori M, Harandi MF, Mirhendi H, Hajialilo E, Kia EB. Sequence analysis of cox 1 and nad 1 genes in Echinococcus granulosus $\mathrm{G} 3$ genotype in camels (Camelus dromedarius) from central Iran. Parasitol Res. 2011;108:521-7.

60. Sharbatkhori M, Tanzifi A, Rostami S, Rostami M, Harandi MF. Echinococcus granulosus sensu lato genotypes in domestic livestock and humans in Golestan Province, Iran. Rev Inst Med Trop Sao Paulo. 2016;58:38.

61. Pezeshki A, Akhlaghi L, Sharbatkhori M, Razmjou E, Oormazdi H, Mohebali $M$, et al. Genotyping of Echinococcus granulosus from domestic animals and humans from Ardabil Province, northwest Iran. J Helminthol. 2013;87:387-91.

62. Nematdoost K, Ashrafi K, Majidi-Shad B, Kia EB, Zeinali A, Sharifdini M. Genetic characterization of Echinococcus granulosus sensu lato in livestock and human isolates from north of Iran indicates the presence of $E$. ortleppi in cattle. Acta Parasitol. 2021;66:446-54.

63. Busi M, Šnábel V, Varcasia A, Garippa G, Perrone V, De Liberato C, et al. Genetic variation within and between $\mathrm{G} 1$ and $\mathrm{G} 3$ genotypes of Echinococcus granulosus in Italy revealed by multilocus DNA sequencing. Vet Parasitol. 2007;150:75-83

64. Hajialilo E, Harandi MF, Sharbatkhori M, Mirhendi H, Rostami S. Genetic characterization of Echinococcus granulosus in camels, cattle and sheep from the south-east of Iran indicates the presence of the G3 genotype. J Helminthol. 2012;86:263-70.

65. Mario L, Takano K, Brochado JF, Costa CV, Soares AG, Yamano K, et al. Infection of humans and animals with Echinococcus granulosus (G1 and G3 strains) and E. ortleppi in southern Brazil. Vet Parasitol. 2011:177:97-103.

66. Shariatzadeh SA, Spotin A, Gholami S, Fallah E, Hazratian T, MahamiOskouei $\mathrm{M}$, et al. The first morphometric and phylogenetic perspective on molecular epidemiology of Echinococcus granulosus sensu lato in stray dogs in a hyperendemic Middle East focus, northwestern Iran. Parasit Vectors. 2015;8:409.

67. Sharma M, Sehgal R, Fomda BA, Malhotra A, Malla N. Molecular characterization of Echinococcus granulosus cysts in north Indian patients: identification of G1, G3, G5 and G6 genotypes. PLoS Negl Trop Dis. 2013;7:e2262

68. Rajabloo M, Hosseini SH, Jalousian F. Morphological and molecular characterisation of Echinococcus granulosus from goat isolates in Iran. Acta Trop. 2012;123:67-71.

69. Kesik HK, Celik F, Simsek S, Kilinc SG, Ahmed H, Gul A. Molecular characterization and haplotype analyses of lung hydatid cyst isolates of cattle and first report of Echinococcus canadensis (G6/G7) in cattle isolates in Turkey. Acta Parasitol. 2021. https://doi.org/10.1007/ s11686-021-00432-1.

70. Kamenetzky L, Gutierrez AM, Canova SG, Haag KL, Guarnera EA, Parra $A$, et al. Several strains of Echinococcus granulosus infect livestock and humans in Argentina. Infect Genet Evol. 2002;2:129-36.

71. Soriano SV, Pierangeli NB, Pianciola L, Mazzeo M, Lazzarini LE, Saiz MS, et al. Molecular characterization of Echinococcus isolates indicates goats as reservoir for Echinococcus canadensis G6 genotype in Neuquén, Patagonia Argentina. Parasitol Int. 2010;59:626-8.

72. Khan A, Ahmed H, Simsek S, Liu H, Yin J, Wang Y, et al. Molecular characterization of human Echinococcus isolates and the first report of E. canadensis (G6/G7) and E. multilocularis from the Punjab Province of Pakistan using sequence analysis. BMC Infect Dis. 2020;20:262.

73. Casulli A, Zeyhle E, Brunetti E, Pozio E, Meroni V, Genco F, et al. Molecular evidence of the camel strain (G6 genotype) of Echinococcus granulosus in humans from Turkana, Kenya. Trans R Soc Trop Med Hyg. 2010;104:29-32.

74. Rojas CAA, Romig T, Lightowlers MW. Echinococcus granulosus sensu lato genotypes infecting humans-review of current knowledge. Int J Parasitol. 2014:44:9-18.

75. Simsek S, Kaplan M, Ozercan IH. A comprehensive molecular survey of Echinococcus granulosus in formalin-fixed paraffin-embedded tissues in human isolates in Turkey. Parasitol Res. 2011;109:411-6.

76. Pednekar RP, Gatne ML, Thompson RA, Traub RJ. Molecular and morphological characterisation of Echinococcus from food producing animals in India. Vet Parasitol. 2009;165:58-65.
77. Addy F, Wassermann M, Banda F, Mbaya H, Aschenborn J, Aschenborn O, et al. Genetic polymorphism and population structure of Echinococcus ortleppi. Parasitology. 2017;144:450-8.

78. Ahmed ME, Eltom KH, Musa NO, Ali IA, Elamin FM, Grobusch MP, et al. First report on circulation of Echinococcus ortleppi in the one humped camel (Camelus dromedaries), Sudan. BMC Vet Res. 2013;9:127.

79. Ebrahimipour M, Sadjjadi SM, Darani HY, Najjari M. Molecular studies on cystic echinococcosis of camel (Camelus dromedarius) and report of Echinococcus ortleppi in Iran. Iran J Parasitol. 2017;12:323-31.

80. Mbaya H, Magambo J, Njenga S, Zeyhle E, Mbae C, Mulinge E, et al. Echinococcus spp. in central Kenya: a different story. Parasitol Res. 2014;113:3789-94.

81. Alvi MA, Ohiolei JA, Saqib M, Li L, Tayyab MH, Alvi AA, et al. Echinococcus granulosus (sensu stricto)(G1, G3) and E. ortleppi (G5) in Pakistan: phylogeny, genetic diversity and population structural analysis based on mitochondrial DNA. Parasit Vectors. 2020;13:347.

82. Monteiro DU, de Azevedo MI, Weiblen C, Ribeiro TC, Emmanouilidis J, Tonin AA, et al. Echinococcus granulosus sensu stricto, Echinococcus canadensis (G7), and Echinococcus ortleppi in fertile hydatid cysts isolated from cattle in southern Brazil. Acta Trop. 2016;164:41-4.

83. Gracey J, Collins DS, Huey R. Meat hygiene. 10th ed. London: Saunders; 1999. p. 52-3.

84. Boubaker G, Macchiaroli N, Prada L, Cucher MA, Rosenzvit MC, Ziadinov I, et al. A multiplex PCR for the simultaneous detection and genotyping of the Echinococcus granulosus complex. PLoS Negl Trop Dis. 2013;7:e2017.

85. Notredame C, Higgins DG, Heringa J. T-Coffee: a novel method for fast and accurate multiple sequence alignment. J Mol Biol. 2000;302:205-17.

\section{Publisher's Note}

Springer Nature remains neutral with regard to jurisdictional claims in published maps and institutional affiliations.
Ready to submit your research? Choose BMC and benefit from:

- fast, convenient online submission

- thorough peer review by experienced researchers in your field

- rapid publication on acceptance

- support for research data, including large and complex data types

- gold Open Access which fosters wider collaboration and increased citations

- maximum visibility for your research: over $100 \mathrm{M}$ website views per year

At BMC, research is always in progress.

Learn more biomedcentral.com/submissions 